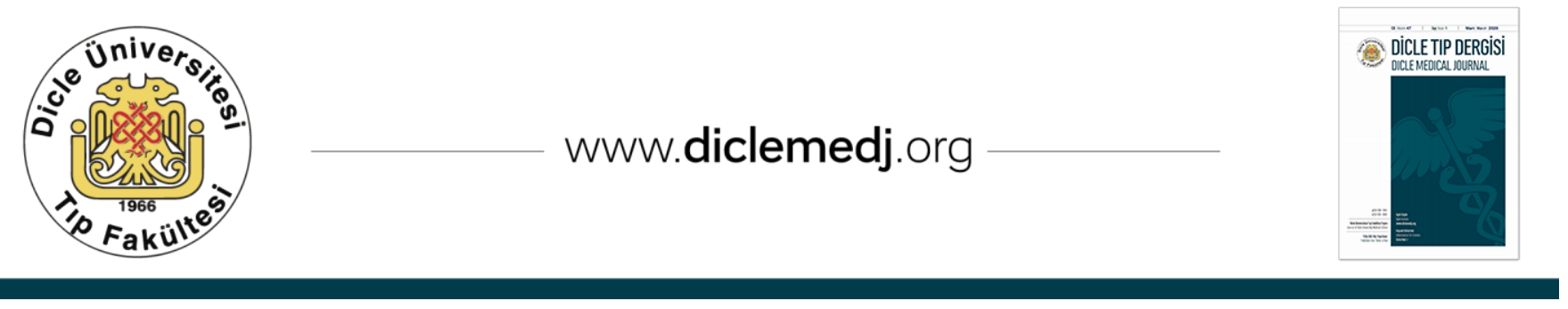

Original Article / Özgün Araştırma

\title{
Decreased CDX2 Expression Adversely Effect On Prognosis Of Patients With Colorectal Cancer
}

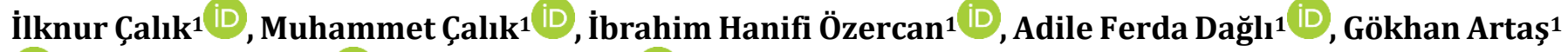 \\ (iD), Gülistan Türken1 ${ }^{\text {iD }}$, Burcu Sarıkaya1 ${ }^{\text {iD }}$ \\ 1 Department of Pathology, Faculty of Medicine, Firat University, Elazığ, Turkey
}

Received: 19.10.2019; Revised: 23.12.2019; Accepted: 07.01.2020

\begin{abstract}
Objective: Since colorectal cancers (CRC) are tumors with heterogeneous biological behavior, prediction of their prognosis remains challenging. Caudal-related homeobox gene 2 (CDX2), which has important roles in the development and maintenance of intestines, is thought to have tumor suppressing effect on CRCs. The aim of this study was to investigate the prognostic significance of decreased-CDX2 expression.

Method: This retrospective study included 224 patients diagnosed with CRC between 2009 and 2014. Paraffinized blocks of these patients were stained with CDX2 immunohistochemically and evaluated semiquantitatively.

Results: Only 35 (15.6\%) of 224 patients had low-CDX2 expression. Decrease in CDX2 expression was closely associated with classical prognostic parameters such as histopathologic type, histologic grade, lymph node metastasis, distant metastasis, and TNM stage. Patients with decreased-CDX2 expression had more lymph node metastasis $(p=0.013)$ and advanced TNM stage $(p=0.004)$ than those without decreased-expression. The mean survival was $53.0 \pm 0.89$ months. Cox regression analysis showed that decreased-CDX2 expression was significantly related with overall survival (Univariate analysis; hazard ratio: $0.09,95 \%$ confidence interval: 0.05-0.16; $\mathrm{p}<0.001$; Multivariate analysis; hazard ratio: $0.24,95 \%$ confidence interval: 0.13-0.48; $\mathrm{p}<0.001$ ) and disease-free survival (Univariate analysis; hazard ratio: 0.80, 95\% confidence interval: 0.05-0.13; $\mathrm{p}<0.001$; Multivariate analysis; hazard ratio: $0.15,95 \%$ confidence interval: $0.08-0.25 ; \mathrm{p}<0.001$ ).
\end{abstract}

Conclusion: Decreased CDX2 expression is significantly related with worse biological features and can be used as an independent prognostic biomarker in patients with CRCs.

Keywords: Colorectal cancer, CDX2, prognosis, overall survival, disease-free survival.

DOI: 10.5798/dicletip.706005

Correspondenc / Yazışma Adresi: Ilknur Calik, Department of Pathology, Faculty of Medicine, Firat University, Elazı̆̆, Turkey e-mail: dr.ilknur23@gmail.com 


\section{Azalmış CDX2 Ekspresyonu Kolorektal Kanserli Hastaların Prognozunu Olumsuz Yönde Etkiliyor}

Öz

Amaç: Kolorektal kanserler heterojen biyolojik davranışa sahip tümörler olduğu için prognozlarının önceden belirlenmesi zorlayıcı olmaya devam etmektedir. Bağırsakların gelişiminde ve devamlılı̆̆ında önemli görevleri olan caudal-related homeobox gene 2 (CDX2)'nin CRC'lerde tümör baskılayıcı etkisi olduğu da düşünülmektedir. Bu çalışmada CDX2 ekspresyonundaki azalmanın prognostik öneminin araştırılması amaçlandı.

Yöntemler: Bu retrospektif çalışmaya 2009-2014 yılları arasında CRC tanısı alan 224 hasta dahil edildi. Bu hastalara ait parafinize bloklar immunohistokimyasal olarak CDX2 ile boyanıp semikantitatif olarak değerlendirildi.

Bulgular: İki yüz yirmi dört hastanın sadece 35'inde (15.6\%) düşük CDX2 ekspresyonu vardı. CDX2 ekspresyonundaki azalma histopatolojik tip, histolojik derece, lenf nodu metastazı, uzak metastaz ve TNM evresi gibi klasik prognostik parametreler ile yakından ilişkiliydi. CDX2 ekspresyonunda azalma olan hastalarda, ekspresyonda azalma olmayanlara göre daha fazla lenf nodu metastazı ve ileri TNM evresi vardı. Ortalama sağkalım 53.0 \pm 0.89 ay olarak belirlendi. Cox regresyon analizi, azalmış CDX2 ekspresyonunun genel sağkalım (Tek değişkenli analiz; tehlike oranı: 0.09, \%95 güven aralığı: 0.05-0.16; $\mathrm{p}<0.001$; Çok değişkenli analiz; tehlike oranı: 0.24, \%95 güven aralığı: 0.13-0.48; $\mathrm{p}<0.001$ ) ve hastalıksız sağkalımla (Tek değişkenli analiz; tehlike oranı: 0.80, \%95 güven aralığı: 0.05-0.13; $\mathrm{p}<0.001$; Çok değişkenli analiz; tehlike oranı: 0.15, \%95 güven aralığı: 0.08-0.25; $p<0.001$ ) önemli ölçüde ilişkili olduğunu gösterdi.

Sonuç: CDX2 ekspresyonunun azalması, daha kötü biyolojik özelliklerle önemli ölçüde ilişkilidir ve CRC'li hastalarda bağımsız bir prognostik biyobelirteç olarak kullanılabilir.

Anahtar kelimeler: Kolorektal kanser, CDX2, prognoz, genel sağkalım, hastalıksız sağkalım.

\section{INTRODUCTION}

Colorectal cancer (CRC) is the third most common cancer all around the World. With an increasing incidence in developing countries, it continues to be a major public health problem ${ }^{1-3}$. Despite surgical treatments, current chemotherapy protocols and multidisciplinary approaches, the prognosis of the disease is still poor. Classical prognostic parameters such as histopathological type, histologic grade, and stage are often used to predict the prognosis of CRC, but patients with the same stage or histological grade often exhibit inhomogeneous biological behavior. Moreover, despite the use of these classic prognostic parameters, reliable prognostic biomarkers for CRC are not yet available. In conclusion, identifying new and easily applicable biomarkers will help in developing reliable prognostic procedures and new treatment modalities for $\mathrm{CRC}^{3,4}$.

The caudal-type homeobox transcription gene-2 (CDX2) is an especial molecule that has a important influence on the development, differentiation, and continuousness of intestine 3 3,5,6. The expression of CDX2 encompasses an area extending from the duodenum to the rectum, particularly limited to the nuclei of intestinal epithelial cells ${ }^{3,7}$. Thus, CDX2 is regarded as a specific determiner of intestinal epithelial cells and is used as an extremely important marker in the differential diagnosis of metastatic adenocarcinomas 7,8 . In addition to its differential diagnostic value and the significant role in development with the differentiation of intestinal epithelial cells, CDX2 gene is known to have tumor suppressing property in $\mathrm{CRC}^{2,9}$. Although strong nuclear immunoreactivity of CDX2 is seen in the majority of CRC cases, decrease or complete loss in CDX2 expression has been reported in $10-30 \%$ of cases $^{7,10}$. In addition, the decrease in CDX2 expression is associated with classical prognostic markers such as histological grading, proximal tumor location, and stage ${ }^{10,11}$. Previous studies have shown that the decrease in CDX2 expression adversely affects on the prognosis and survival of patients with CRC. On the other hand, the 
independent prognostic worth of CDX2 expression loss is still disputable ${ }^{7,11,12}$.

In this study, we aimed to investigate the effect of decreased-CDX2 expression on the prognosis of CRC patients. In addition, the correlation between CDX2 expression and classical prognostic parameters was investigated.

\section{METHODS}

This study was approved by Firat University Ethical Committee (Date: 17.09.2019, Approval No: 13-08). We retrospectively evaluated the pathological specimens of 224 patients who had undergone surgery for CRC between 2009 and 2014 at Firat University Hospital. Patients who were treated with chemotherapy were not included in the study. A control group $(n=224)$ consisting of non-tumoural colorectal tissues from the same patients was included in the study. Two pathologists histologically re-evaluated each pathologic material. The clinical and pathological data were acquired from hospital medical and pathologic reports. The tumour-node-metastases (TNM) stages of the cases were specified according to the American Joint Committee on Cancer (AJCC), 7 th edition ${ }^{13}$. Survival data included patient outcome and the interval between the date of surgical resection and the date of death.

Immunohistochemistry (IHC) was performed using $4 \mu \mathrm{m}$ thick histological tissue slides obtained from paraffin blocks of 224 CRC patients. The following antibody was used: anti-CDX2 (clone DAK-CDX2; Dako, Glostrup, Denmark). The sections were stained using the Ventana Bench mark Ultra autostainer (Ventana) and the ultraView Universal DAB kit (Ventana), following the manufacturer's instructions. CDX2 expression was evaluated by IHC. When evaluating CDX2 expression, non-tumoural colorectal mucosa was utilized as internal positive controls.

The expression of CDX2 in tumor cells was evaluated by immunohistochemical staining method and scored semi-quantitatively. Only nuclear positivity in tumor cells was accepted for evaluation. Both staining ratio (percentage of stained cells) and intensity were taken into consideration when evaluating. The staining ratio was scored as $0(0 \%)$, 1 ( $>0 \%$ to $25 \%$ ), 2 ( $>25 \%$ to $50 \%$ ), 3 ( $>50 \%$ to $75 \%$ ), or $4(>75 \%)$, while the intensity was scored as 0 (negative), 1 (weakly positive), 2 (moderately positive), or 3 (strongly positive). The final staining score was calculated by multiplying the proportion score by the intensity score. Samples with a staining score of $\leq 4$ comprised the low-expression group, and those with a score of $>4$ comprised the highexpression group ${ }^{11}$.

The data were analysed statistically using SPSS software version 20.0 and were expressed as percentages, means and standard deviations. The normal distribution of the data was evaluated with the Shapiro-Wilk test. P values $>0.05$ were accepted as indicating a normal distribution. Kurtosis and skewness values between -2 and +2 were also considered to indicate a normal distribution. The Pearson test was used to investigate the relationship between normally distributed data. An independent sample t-test and ANOVA were used to identify variances between the groups. The chi-square test was used to determine the relationship between data that were not normally distributed. The relationships between overall survival (OS)/diseasefree survival (DFS) and CDX2 expression were evaluated using the Kaplan-Meier method (log-rank test). Cox regression analysis was applied to estimate the hazard ratios (HRs) and 95\% confidence intervals (CIs) for univariate and multivariate models. The $\mathrm{P}<0.05$ threshold was considered statistically significant for all data.

\section{RESULTS}

Of patients, 93 were women and 131 were men. The mean patient age was $60.2 \pm 0.92$ years, and the mean follow-up time was $53.0 \pm 0.89$ months. The tumor was localized in the right colon of 135 (60.3\%) patients and in the left colon those of 89 (39.7\%). Thirty three $(14.7 \%)$ of the cases included in the study were TNM stage I, 75 (33.5) were stage II, 92 (41.1\%) were stage III and $24(10.7 \%)$ were stage IV. The comprehensive clinicopathologic features are showed in Table 1 . The Cox regression analysis (both univariate and multivariate) showed that age, tumor site, histopathological type, grade, depth of invasion (pT), lymph node metastasis (pN), distant metastasis and high TNM stage were significantly correlated with poor prognosis (Table 1). 
Calik I.,Calik M.,Ozercan I.H., Dagli A.F., Artas G.,Turken G., Sarikaya B.

Table I. General features of cases and correlation of clinicopathologic characteristics with overall survival / disease-free survival $(n=224)$

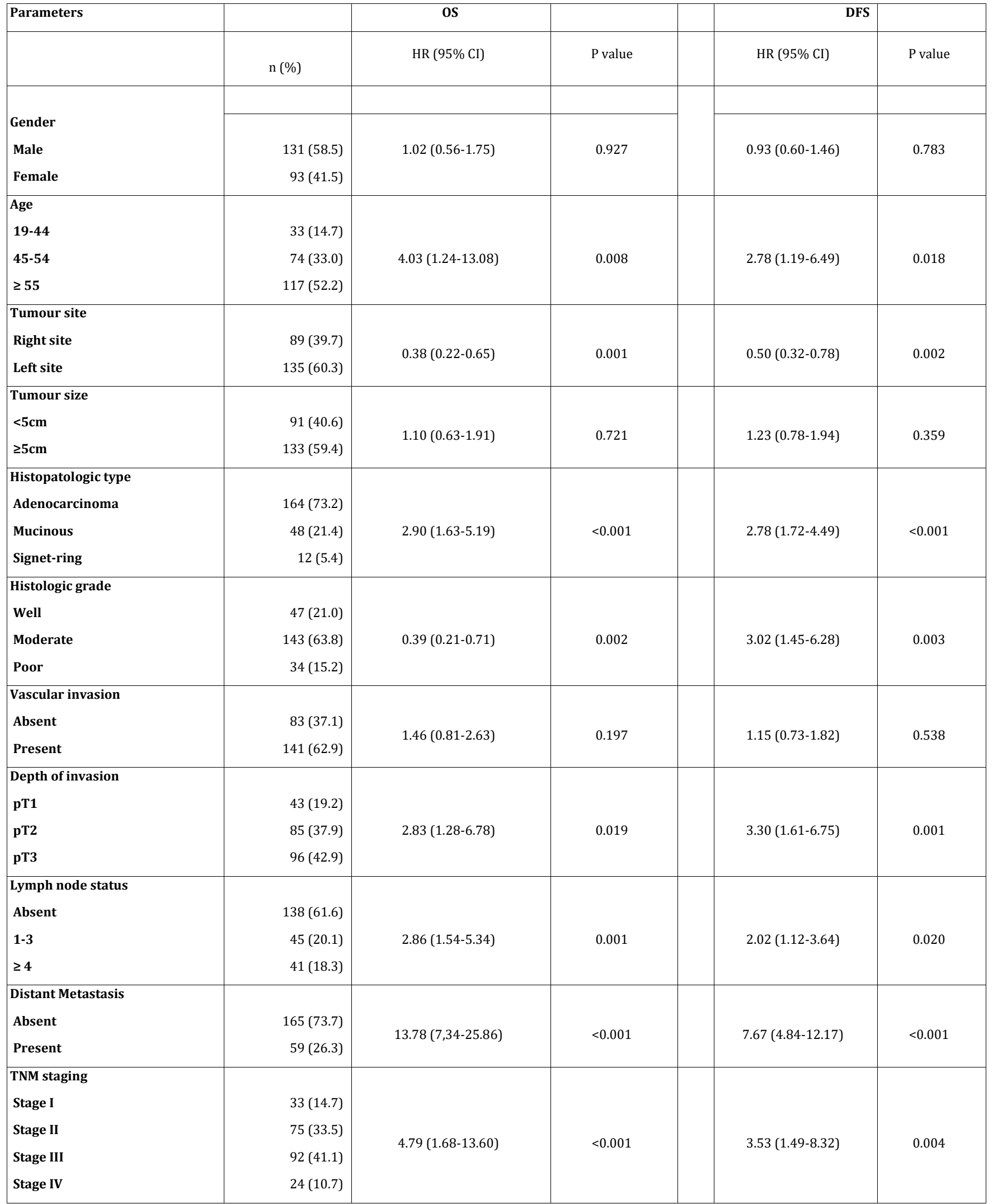


OS: overal survival, DFS: disease-free survival, HR: Hazard ratio, CI: confidence interval

Among these, histopathological type and distant metastasis were determined to be more associated with survival. Mean OS in cases with welldifferentiated adenocarcinoma were $55.09 \pm 0.89$ months, whereas it was significantly lower in cases with signet ring cell carcinoma (44.91 \pm 4.22 months). Similarly, the mean OS of patients with distant metastasis was significantly lower than those without $(39.64 \pm 1.95$; $57.78 \pm 0.61$; respectively). In contrast, according to our data, there was no correlation between sex, tumor size, and vascular invasion and OS/DFS (Table 1).

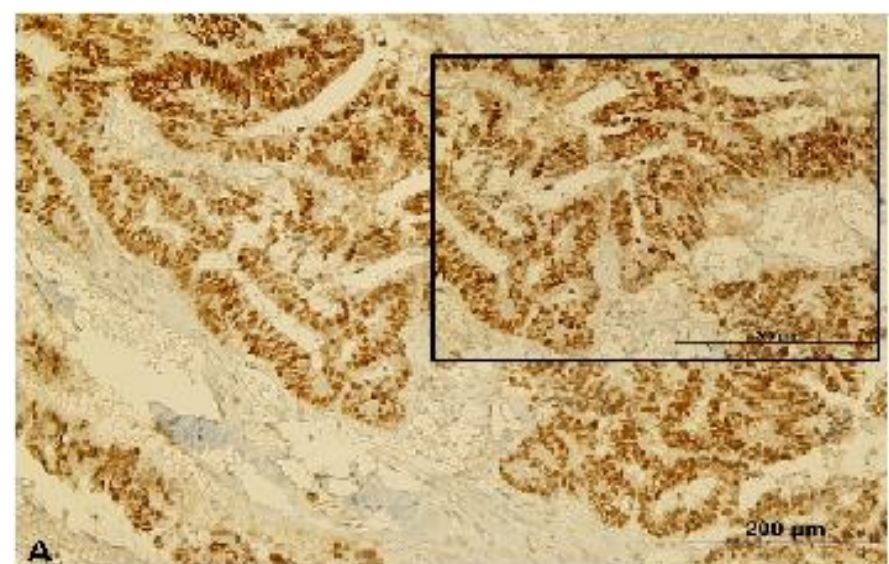

Figure 1A-B. The CDX2 expression status of patients with colorectal cancer (CDX2 x 200 and CDX2 x 400). High expression of CDX2 (A), and loss of CDX2 expression (B)

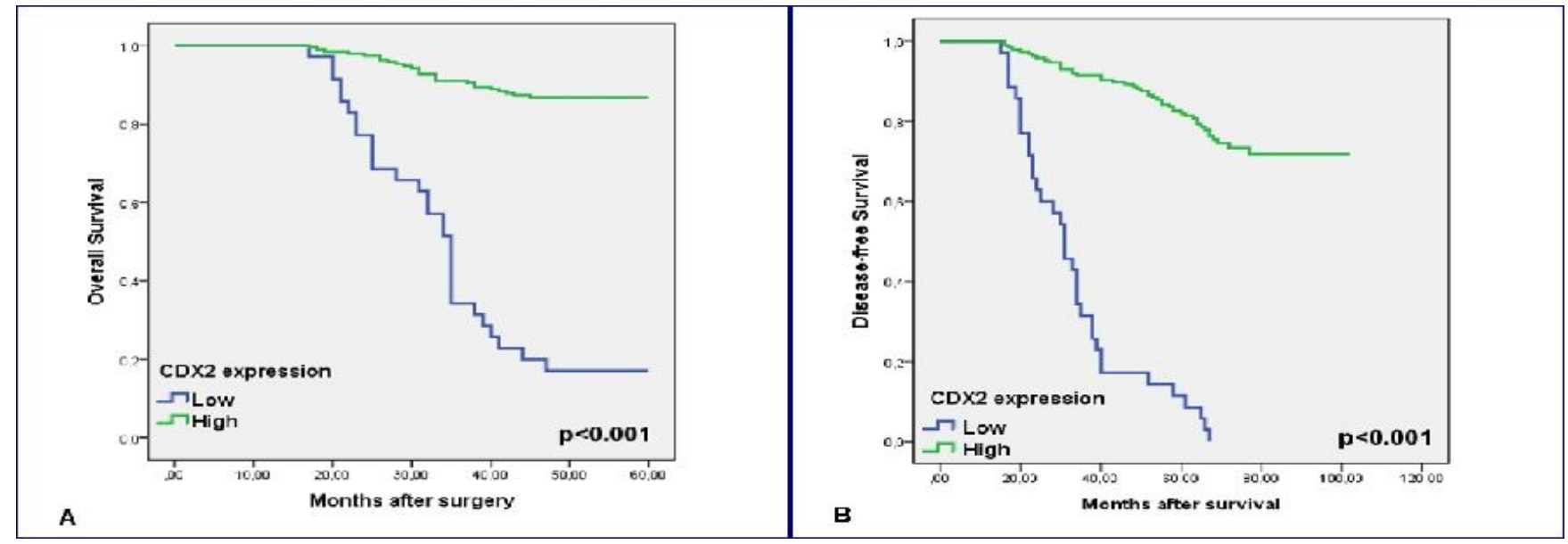

Figure 2A-B. Kaplan-Meier survival diagrams according to CDX2 expression status in patients with colorectal cancers. Overall survival $(\mathrm{P}<0.001)(\mathrm{A})$; Disease-free survival $(\mathrm{P}<0.001)(\mathrm{B})$. Green line: high-CDX2 expression, blue line: low-CDX2 expression.

Survival data for these patients were collected from 13 July 2009 to 22 September 2014. During follow-up, 54 patients died and 80
In our study, high CDX2 expression (Figure 1A) was observed in 189 (84.4\%) of the cases, whereas decrease in CDX2 expression (Figure 1B) was detected in only $35(15.6 \%)$ of 224 cases. The decreased-CDX2 expression was associated with, advanced age $(\mathrm{p}=0.023)$, histological type $(p<0.001)$, vascular invasion $(\mathrm{p}<0.001), \quad \mathrm{pN}$ $(\mathrm{p}=0.013)$, distant metastasis $(\mathrm{p}<0.001)$ and high TNM stage $(\mathrm{p}=0.004)$. Besides, on histopathological assessment, cases with a decreased-CDX2 expression displayed a close association with poor differentiation $(\mathrm{P}=0.001)$. However, there was no significant correlation between CDX2 expression and sex, tumor site, tumor size, and pT (Table 2).

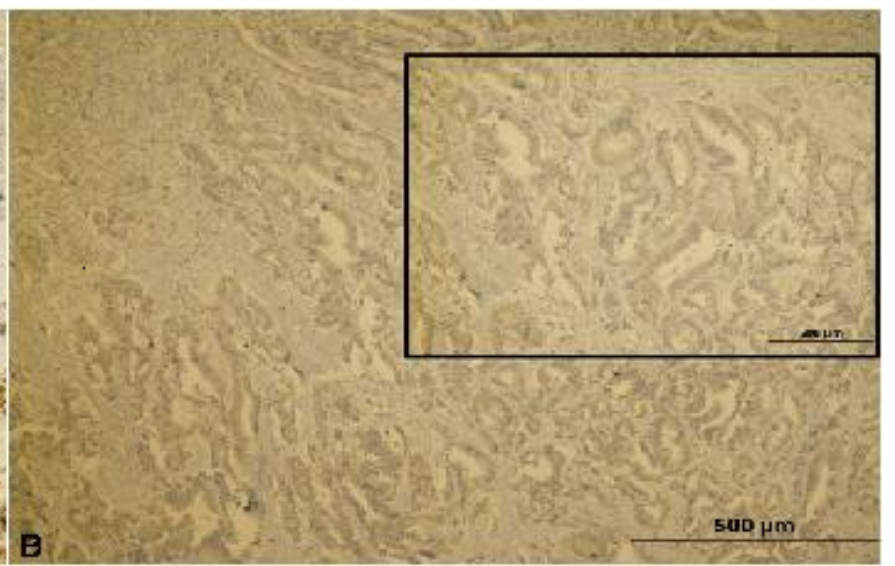


(34.77 \pm 2.22 month) than those $(56.20 \pm 0.73$ month) with high CDX2 expression (Table 3). In addition, according to both univariate and multivariate Cox regression analysis, CDX2 expression was closely related to OS and DFS (Table 3). Patients with low-CDX2 expression had a shorter DFS time (33.40 \pm 2.53 month) than those with high-CDX2 expression (57.14 \pm 1.97 month) (Figure 2B). Multivariate survival analysis manifested that decrease of CDX2 expression was an independent and poor prognostic parameter for both OS (HR 0.24; 95\% CI: 0.13-0.48; $\mathrm{p}<0.001$ ) and DFS (HR: 0.15; 95\% CI: 0.08-0.25; $\mathrm{p}<0.001$ ).

Table II. The relationship between CDX2 expression and classical clinicopathological parameters.

\begin{tabular}{|c|c|c|c|c|}
\hline \multirow[t]{2}{*}{ Parameters } & & \multicolumn{2}{|c|}{ CDX2 expression } & \multirow[b]{3}{*}{$P$ value } \\
\hline & & Low (n:35) & High (n:189) & \\
\hline & N (\%) & n (\%) & n (\%) & \\
\hline \multicolumn{5}{|l|}{ Gender } \\
\hline Male & $131(58.5)$ & $22(16.8)$ & $109(83.2)$ & \multirow{2}{*}{$0.178 \dagger$} \\
\hline Female & $93(41.5)$ & $13(14.0)$ & $80(86.0)$ & \\
\hline \multicolumn{5}{|l|}{ Age } \\
\hline $19-44$ & $33(14.7)$ & $2(6.1)$ & $31(93.9)$ & \multirow{3}{*}{$0.023 \dagger$} \\
\hline $45-54$ & $74(33.0)$ & $10(13.5)$ & $64(86.5)$ & \\
\hline$\geq 55$ & $117(52.2)$ & 23 (19.7) & $94(80.3)$ & \\
\hline \multicolumn{5}{|l|}{ Histopatologic type } \\
\hline Adenocarcinoma & $164(73.2)$ & $17(10.4)$ & $147(89.6)$ & \multirow{3}{*}{$<0.001 \dagger$} \\
\hline Mucinous & $48(21.4)$ & $13(27.1)$ & 35 (72.9) & \\
\hline Signet-ring & $12(5.4)$ & $5(41.7)$ & $7(58.3)$ & \\
\hline \multicolumn{5}{|l|}{ Histologic grade } \\
\hline Well & $47(21.0)$ & $3(6.4)$ & 44 (93.6) & \multirow{3}{*}{$0.001 \neq$} \\
\hline Moderate & $143(63.8)$ & $20(14.0)$ & $123(86.0)$ & \\
\hline Poor & $34(15.2)$ & $12(35.3)$ & $22(64.7)$ & \\
\hline \multicolumn{5}{|l|}{ Depth of invasion } \\
\hline pT1 & 43 (19.2) & $7(16.3)$ & 36 (83.7) & \multirow{3}{*}{$0.276 \dagger$} \\
\hline pT2 & 85 (37.9) & $6(10.6)$ & $76(89.4)$ & \\
\hline pT3 & $96(42.9)$ & 19 (19.8) & $77(80.2)$ & \\
\hline \multicolumn{5}{|l|}{ Lymph node status } \\
\hline Absent & $138(61.6)$ & $9(6.5)$ & $129(93.5)$ & \multirow{3}{*}{$0.013 \neq$} \\
\hline 1-3 & $45(20.1)$ & $11(24.4)$ & $34(75.6)$ & \\
\hline$\geq 4$ & $41(18.3)$ & $15(36.6)$ & $26(63.4)$ & \\
\hline \multicolumn{5}{|l|}{ Vascular invasion } \\
\hline Absent & $83(37.1)$ & $8(9.6)$ & $75(90.4)$ & \multirow{2}{*}{$<0.001 \dagger$} \\
\hline Present & 141 (62.9) & $27(19.1)$ & $114(80.9)$ & \\
\hline \multicolumn{5}{|l|}{ Distant Metastasis } \\
\hline Absent & 165 (73.7) & $9(5.5)$ & $156(94.5)$ & \multirow{2}{*}{$<0.001 \neq$} \\
\hline Present & $59(26.3)$ & $26(44.1)$ & 33 (55.9) & \\
\hline \multicolumn{5}{|l|}{ TNM staging } \\
\hline Stage I & 33 (14.7) & $4(12.1)$ & 29 (87.9) & \multirow{4}{*}{$0.004 \ddagger$} \\
\hline Stage II & $75(33.5)$ & $5(6.7)$ & $70(93.3)$ & \\
\hline Stage III & $92(41.1)$ & $18(19.6)$ & $74(80.4)$ & \\
\hline Stage IV & $24(10.7)$ & $8(33.3)$ & $16(66.7)$ & \\
\hline
\end{tabular}

t: Samples T Test, $\neq:$ Mann-Whitney $U$

Table III. Cox regression analysis (univariate and multivariate) of CDX2 expression associated with disease-free survival.

\begin{tabular}{|c|c|c|c|c|c|}
\hline \multirow{2}{*}{$\begin{array}{l}\text { Surviva } \\
1\end{array}$} & \multicolumn{5}{|c|}{ CDX2 expression } \\
\hline & $\begin{array}{c}\text { Low } \\
(\mathrm{MS} \pm \mathrm{S} . \mathrm{E})\end{array}$ & $\begin{array}{c}\text { High } \\
\text { (MS } \pm \text { S.E) }\end{array}$ & $\begin{array}{c}\text { Univariat } \\
\text { e }\end{array}$ & $\begin{array}{c}\text { Multivariat } \\
\text { e } \\
\text { HR (95\% } \\
\text { CI) }\end{array}$ & $\begin{array}{c}P \\
\text { value }\end{array}$ \\
\hline OS & $\begin{array}{c}34.77 \pm 2.2 \\
2\end{array}$ & $\begin{array}{c}56.20 \pm 0.7 \\
3\end{array}$ & $\begin{array}{c}0.09(0.05- \\
0.16)\end{array}$ & $\begin{array}{c}0.24(0.13- \\
0.48)\end{array}$ & $\begin{array}{c}<0.00 \\
1\end{array}$ \\
\hline DFS & $\begin{array}{c}33.40 \pm 2.5 \\
3\end{array}$ & $\begin{array}{c}57.14 \pm 1.9 \\
7\end{array}$ & $\begin{array}{c}0.80(0.05- \\
0.13)\end{array}$ & $\begin{array}{c}0.15(0.08- \\
0.25)\end{array}$ & $\begin{array}{c}<0.00 \\
1\end{array}$ \\
\hline
\end{tabular}

MS: mean survival, SE: standart error, HR: hazard ratio, CI: confidence interval, OS: overall survival, DFS: disease-free survival

\section{DISCUSSION}

It is extremely important to establish exactly predictive systems or biomarkers in identifying low and high risk groups and improving suitable treatment modalities for patients with CRC. In this study, we investigated the effect of CDX2 expression and classical clinicopathological parameters on the prognosis of patients with CRC.

According to our data, decreased-CDX2 expression is an independent prognostic factor for CRC that is compatible with the results of previous researches $7,11,12,14$. In the Cox regression analyse, we revealed CDX2 expression was significantly related with the survival of CRC similar to pT and $\mathrm{pN}$. Particularly, patients with high-CDX2 expression and those with pT1 revealed longer OS/DFS than others. Unlike this, patients with 
low-CDX2 expression and those with pT3 had the worst clinical outcome. In addition, the cases with signet ring cell carcinoma had a worse prognosis than well-differentiated adenocarcinoma ones.

Olsen et al. suggested that a loss of CDX2 expression was correlated to histological grade, TNM stage and tumour site ${ }^{15}$. Dalerba et al., emphasised that the prognostic specificity of decreased-CDX2 was independent of other confusing classical parameters such as age, tumour site, histological grade and $\mathrm{pT}^{14}$. Again in a research supporting this study, Hansen et al. showed that the decrease of CDX2 expression was an independent prognostic biomarker from age, sex, pT, vascular invasion, and perineural invasion ${ }^{16}$. Similarly, Lugli et al. found that the loss of CDX2 expression is related with a higher $\mathrm{pT}, \mathrm{pN}$, histological grade, vascular invasion and tumour site (particularly right site) in CRC 17 . Consistent with these studies, CDX2-loss was showed to be an independent prognostic indicator in our study (both univariate and multivariate analyzes). Besides, in present study, decrease of CDX2 expression was significantly correlated with tumour type, histological grade, $\mathrm{pN}$ and TNM stage. But, unlike the results of Lugli et al., there was no meaningful correlation between CDX2 expression and $\mathrm{pT}$.

As in many malignant neoplasms, the presence of solid organ metastasis in colorectal cancers adversely affects on the prognosis. Unfortunately, a quarter of patients with primary CRC have hepatic metastasis at the time of diagnosis, and more than $50 \%$ of patients develop liver metastases later in life. Even worse, the survival time in metastatic patients is less than three years ${ }^{18,19}$. The relationship between CDX2 expression and distant metastasis is still controversial. Shigematsu et al. showed that difference in CDX2 expression severity between primary CRCs and liver metastases were not significant ${ }^{6}$. On the contrary, according to the study of 101 cases by Tóth et al., there was a significant relationship between lack of CDX2 expression and the liver metastasis $^{18}$. In a later study by Shigematsu et al., it was emphasized that patients with low CDX2 expression had higher metastasis rates than high expression ones ${ }^{5}$. In present study, consonant with previous studies, there was a significant correlation between CDX2 expression and distant metastasis. While patients with high CDX2 expression had a lower rate of metastasis, distant metastasis was seen to be more in the group with low-expression $(\mathrm{p}<0.001$, Mann Whitney U Test).

There are studies including univariate analysis which is emphasize that decreased-CDX2 expression in CRC patients has a negative impact on overall and disease-free survival ${ }^{20-22}$. There is still dispute, however, as to whether lack of CDX2 expression is an independent prognostic parameter in patients with CRC. In two prospective cohort studies involving six patients with $\mathrm{CRC}^{21}$, Baba et al. investigated the interrelationship between lack of CDX2 and clinicopathologic and molecular parameters ${ }^{20}$. They found that a significant correlation between CDX2 loss and high mortality rates according to univariate analysis. In a multivariate analysis, however, no significant relation was found between decrease-CDX2 and disease-free survival and overall survival. Even so, when survival rates were limited to patients with a family history of CRC, Baba et al. revealed that a significant interrelation between decreased-CDX2 expression and survival in a multivariate analysis. Dawson et al. stated that decreased-CDX2 expression was associated with $\mathrm{pT}, \mathrm{pN}$ and poor survival in multivariate analysis without distant metastasis staging 22 .

As a result, we evaluated the intensity of CDX2 expression using immunohistochemical methods in 224 patients with CRC and investigated whether there was a relationship between decreased-CDX2 expression and 
classical clinicopathological parameters and survival. According to our data, decreasedCDX2 expression was closely related to histopathologic type, histological grade, $\mathrm{pT}, \mathrm{pN}$ and high TNM stage. In patients with lack of expression, more distant metastasis was detected. Moreover, according to the Cox proportional hazard model carried out with univariate and multivariate analysis, the decreased-CDX2 expression adversely affected on OS and DFS. Therefore, the decreased-CDX2 expression is an independent prognostic parameter and is a candidate molecule to become an important biomarker in patients with CRC.

In our opinion, our study has some limitations. First, it was a retrospective, single-institution study, so the potential exists for selection bias. Secondly, since our study was a long-term retrospective study, data loss and deficiencies in archive records were inescapable. Thirdly, our study was limited for generalizations as it included data from a single center. To consolidate and validate our findings, multicenter studies with large sample sizes should be performed.

Ethics Committee Approval: This study was approved by Firat University Ethical Committee (Date: 17.09.2019, Approval No: 13-08).

Çıkar Çatışması Beyanı: Yazarlar çıkar çatışması olmadığını bildirmişlerdir.

Finansal Destek: Bu çalışma her hangi bir fon tarafından desteklenmemiştir.

Declaration of Conflicting Interests: The authors declare that they have no conflict of interest.

Financial Disclosure: No financial support was received.

\section{REFERENCES}

1. Haddad FG, Eid R, Kourie HR, Barouky E, Ghosn M. Prognostic and predictive biomarkers in nonmetastatic colorectal cancers. Future Oncol 2018; 14: 2097-102.

2. Akdeniz N, Kaplan MA, Küçüköner M, et al. Prognostic importance of primary tumor location in RAS mutant metastatic colorectal cancer. Dicle Med J 2019; 46: 247-53.

3. Slik K, Turkki R, Carpén O, et al. CDX2 Loss With Microsatellite Stable Phenotype Predicts Poor Clinical Outcome in Stage II Colorectal Carcinoma. Am J Surg Pathol 2019; 43: 1473-82.

4. Xiong Y, You W, Hou M, et al. Nomogram Integrating Genomics with Clinicopathologic Features Improves Prognosis Prediction for Colorectal Cancer. Mol Cancer Res 2018; 16: 1373-84.

5. Shigematsu Y, Inamura K, Yamamoto N, et al. Impact of CDX2 expression status on the survival of patients after curative resection for colorectal cancer liver metastasis. BMC Cancer 2018; 18: 980.

6. Shigematsu Y, Inamura K, Mise Y, et al. CDX2 expression is concordant between primary colorectal cancer lesions and corresponding liver metastases independent of chemotherapy: a single-center retrospective study in Japan. Oncotarget 2018; 9: 17056-65.

7. Bae JM, Lee TH, Cho NY, Kim TY, Kang GH. Loss of CDX2 expression is associated with poor prognosis in colorectal cancer patients. World J Gastroenterol 2015; 21: 1457-67.

8. Kaimaktchiev V, Terracciano L, Tornillo L, et al. The homeobox intestinal differentiation factor CDX2 is selectively expressed in gastrointestinal adenocarcinomas. Mod Pathol 2004; 17: 1392-99.

9. Hryniuk A, Grainger S, Savory JG, Lohnes D. $\mathrm{Cdx} 1$ and $\mathrm{Cdx} 2$ function as tumor suppressors. J Biol Chem 2014; 289: 33343-54.

10. Matsuda $M$, Sentani $K$, Noguchi $T$, et al. Immunohistochemical analysis of colorectal cancer with gastric phenotype: claudin-18 is 
associated with poor prognosis. Pathol Int 2010; 60: 673-80.

11. Xu W, Zhu Y, Shen W, et al. Combination of CDX2 expression and $\mathrm{T}$ stage improves prognostic prediction of colorectal cancer. J Int Med Res 2019; 47: 1829-42.

12. Hong KD, Lee D, Lee Y, Lee SI, Moon HY. Reduced CDX2 expression predicts poor overall survival in patients with colorectal cancer. Am Surg 2013; 79: 353-60.

13. Hari DM, Leung AM, Lee JH, et al. AJCC Cancer Staging Manual 7th edition criteria for colon cancer: do the complex modifications improve prognostic assessment? J Am Coll Surg 2013; 217: 181-90.

14. Dalerba P, Sahoo D, Paik S, et al. CDX2 as a prognostic biomarker in stage II and stage III colon cancer. N Engl J Med 2016; 374: 211-22.

15. Olsen J, Espersen ML, Jess P, Kirkeby LT, Troelsen JT. The clinical perspectives of CDX2 expression in colorectal cancer: a qualitative systematic review. Surg Oncol 2014; 23: 16776.

16. Hansen TF, Kjaer-Frifeldt S, Eriksen AC, et al. Prognostic impact of CDX2 in stage II colon cancer: results from two nationwide cohorts. $\mathrm{Br}$ J Cancer 2018; 119: 1367-73.

17. Lugli A, Tzankov A, Zlobec I, Terracciano LM. Differential diagnostic and functional role of the multi-marker phenotype CDX2/CK20/CK7 in colorectal cancer stratified by mismatch repair status. Mod Pathol 2008; 21: 1403-12.

18. Tóth C, Sükösd F, Valicsek E, et al. Loss of CDX2 gene expression is associated with DNA repair proteins and is a crucial member of the Wnt signaling pathway in liver metastasis of colorectal cancer. Oncol Lett 2018; 15: 3586-93.

19. Misiakos EP, Karidis NP and Kouraklis G: Current treatment for colorectal liver metastases. World J Gastroenterol 2011; 17: 4067-75.

20. Baba Y, Nosho K, Shima K, et al. Relationship of CDX2 loss with molecular features and prognosis in colorectal cancer. Clin Cancer Res 2009; 15: 4665-73.

21. Dawson H, Galván JA, Helbling $\mathrm{M}$, et al. Possible role of $\mathrm{Cdx} 2$ in the serrated pathway of colorectal cancer characterized by BRAF mutation, high-level $\mathrm{CpG}$ Island methylator phenotype and mismatch repair-deficiency. Int J Cancer 2014; 134: 2342-51.

22. Dawson H, Koelzer VH, Lukesch AC, et al. Loss of Cdx2 Expression in Primary Tumors and Lymph Node Metastases is Specific for Mismatch RepairDeficiency in Colorectal Cancer. Front Oncol 2013; 3: 265. 